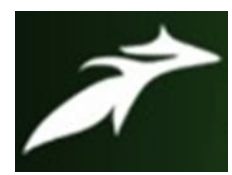

VINOTHKUMAR, R. et al, International Journal of Advances in Agricultural Science and Technology,

Vol.8 Issue.2, February-2021, pg. 39-48

ISSN: 2348-1358

Impact Factor: 6.057

NAAS Rating: 3.77

\title{
RESPONSE OF RICE TO BALANCED FERTILIZATION IN TYPIC USTIFLUVENT SOIL
}

\author{
VINOTHKUMAR, R., ${ }^{1}$; Dr. M.V. SRIRAMACHANDRASEKHARAN² \\ Dr. R. MANIVANNAN ${ }^{3}$ \\ PG Scholar, Professor, Assistant Professor \\ Department of Soil Science and Agricultural Chemistry \\ Faculty of Agriculture, Annamalai University, Annamalainagar-608002 \\ DOI: 10.47856/ijaast.2021.v08i2.006
}

\begin{abstract}
Balanced fertilizer uses in food grain crops including rice is one of the important considerations in providing food security to the burgeoning population and promoting soil quality in sustainable intensive agriculture. Wide spread negative nutrient balance in different production system can be overcome by adopting integrated nutrient management. Field experiments were conducted in farmers holding belonging to Padugai series (Typic Ustifluvents) to investigate the response of rice to balanced fertilization. The treatments employed in the study were $\mathrm{T}_{1}$ ) Control $\mathrm{T}_{2}$ ) Farmer's practice (125, 62.5, $\left.62.5 \mathrm{~kg} \mathrm{~N}, \mathrm{P}_{2} \mathrm{O}_{5}, \mathrm{~K}_{2} \mathrm{O}\right), \mathrm{T}_{3}$ ) 100\% NPKS Zn (120: 38: 38: 20: $5 \mathrm{~kg} \mathrm{~N}, \mathrm{P}_{2} \mathrm{O}_{5}, \mathrm{~K}_{2} \mathrm{O}$, S and $\mathrm{Zn}$ - kharif and 150: 50: 50: 20: $5 \mathrm{~kg} \mathrm{~N}, \mathrm{P}_{2} \mathrm{O}_{5}, \mathrm{~K}_{2} \mathrm{O}, \mathrm{S}$ and $\mathrm{Zn}-$ rabi), $\mathrm{T}_{4}$ ) $\mathrm{T}_{3}$ minus $\mathrm{N}$, $\mathrm{T}_{5}$ ) $\mathrm{T}_{3}$ minus $\left.\mathrm{P}, \mathrm{T}_{6}\right) \mathrm{T}_{3}$ minus $\left.\mathrm{K}, \mathrm{T}_{7}\right) \mathrm{T}_{3}$ minus PK, $\mathrm{T}_{8}$ ) $\mathrm{T}_{3}$ minus $\mathrm{S}, \mathrm{T}_{9}$ ) $\mathrm{T}_{3}$ minus $\left.\mathrm{Zn}, \mathrm{T}_{10}\right) \mathrm{T}_{3}$ minus $\mathrm{S} \mathrm{Zn}, \mathrm{T}_{11}$ ) $75 \% \mathrm{NPK}+\mathrm{S}+\mathrm{Zn}+\mathrm{PM} @ 4 \mathrm{tha}^{-1}$ and $\left.\mathrm{T}_{12}\right) 50 \% \mathrm{NPK}+\mathrm{S}+\mathrm{Zn}+\mathrm{PM} @ 4 \mathrm{tha}^{-1}$. The test crop was rice with variety ADT 43 (Kharif) and BPT 5204 (Rabi). The experiment was conducted in RBD design with three replications. The highlight of the outcome was All the treatment caused a significant increase in growth and yield over control. The tallest plant, highest tiller count, LAI, chlorophyll content was observed with treatment involving 75\% NPK + S + Zn + PM @ 4tha ${ }^{-1}$ and was closely followed by 100\% NPKS Zn and 50\% NPK + S + $\mathrm{Zn}+\mathrm{PM} @ 4 \mathrm{t} \mathrm{ha}^{-1}$. The highest grain yield $\left(5650,6080 \mathrm{~kg} \mathrm{ha}^{-1}\right)$, straw yield $\left(6910,7418 \mathrm{~kg} \mathrm{ha}^{-1}\right)$, highest grain yield response $\left(2905,2925 \mathrm{~kg} \mathrm{ha}^{-1}\right)$, percent increase in grain $(105.8,116.9)$ and straw (108. 114.1) in kharif and rabi respectively was realised in $75 \% \mathrm{NPK}+\mathrm{S}+\mathrm{Zn}+\mathrm{PM} @ 4 \mathrm{t} \mathrm{ha}^{-1}$. There was perceptible reduction in growth and yield of rice, where there was omission of single or two nutrients in the fertilizer schedule. To conclude, balanced fertilization with INM strategy not only maximizes the rice yield but also maintains soil health and nutrient savings.
\end{abstract}

KEYWORDS: growth, yield, rice, omission, balanced fertilization

\section{INTRODUCTION}

Rice is the staple food for about 50 per cent of the world's population (72.7 billion) that resides in Asia, where 90 per cent of the world's rice is grown and consumed. It is an important staple food that provides 66 to 70 per cent body calorie intake of the consumers (Barah and Pandey, 2005). India had approximately 44 million hectares of land area for cultivation of rice. Cereal production in the country increased by fivefold, while fertilizer consumption increased 322 times during the 1950-51 to 2007-08 period, implying a very low fertilizer 


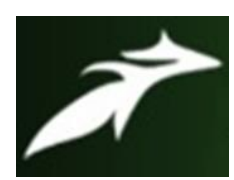

VINOTHKUMAR, R. et al, International Journal of Advances in Agricultural Science and Technology, Vol.8 Issue.2, February-2021, pg. 39-48

ISSN: 2348-1358

Impact Factor: 6.057

NAAS Rating: 3.77

use efficiency (Rajendra Prasad 2009). The magnitude of 30\% yield decline over a 20 -year period due to declining soil nitrogen supply was estimated by Cassman and Pingali (1993). Single nutrient approach has often caused reduced FUE and consequently problems of multiple nutrient use efficiency in cereal-based cropping system. The response of crop to $\mathrm{N}$ not only depends on the status of $\mathrm{N}$ but also on deficiency or sufficiency of other associate plant nutrients (Acharya and Sharma, 2008). Widespread deficiencies of N, P, K, S and Zn have made these five nutrients so practically important that successful crop production in many parts of the India depends on the use two or more of these nutrients. Balanced fertilization of NPK and other deficient nutrients in different crops proved better for higher crop yields and correct nutrient mining under intensive cropping system. Balanced fertilizer coupled with INM is indispensable to arrest yield decline and ensure higher production in accordance with nutrient demand by crops without causing harm to environment (Borah et al., 2016). In this context, field experiments were conducted to ascertain the impact of balanced fertilization on rice grown in typic ustifluvent soil.

\section{MATERIALS AND METHODS}

Field experiments were conducted in Padugai series (Typic Ustifluvent) during kharif and rabi seasons of 2016 to understand the impact of balanced fertilization on rice. The experimental soil was sandy clay loam in texture, $\mathrm{pH}-7.25, \mathrm{EC}\left(\mathrm{dSm}^{-1}\right)-0.15$. SOC- $3.5 \mathrm{~g} \mathrm{~kg}^{-1}, \mathrm{KMnO}_{4}-\mathrm{N}-251 \mathrm{~kg} \mathrm{ha}^{-1}$ (low), Olsen-P- $17.4 \mathrm{~kg}$ ha ${ }^{1}$ (medium), $\mathrm{NH}_{4} \mathrm{OAc}-\mathrm{K}-228 \mathrm{~kg} \mathrm{ha}^{-1}$ (medium), $\mathrm{CaCl}_{2}-\mathrm{S}-12.5 \mathrm{mg} \mathrm{kg}^{-1}$ (sufficient) and DTPA-Zn- $0.90 \mathrm{mg} \mathrm{kg}$ ${ }^{1}$ (deficient). The treatment structure was $\mathrm{T}_{1}$ ) Control $\mathrm{T}_{2}$ ) Farmer's practice $\left(125,62.5,62.5 \mathrm{~kg} \mathrm{~N}, \mathrm{P}_{2} \mathrm{O}_{5}, \mathrm{~K}_{2} \mathrm{O}\right)$, $\mathrm{T}_{3}$ ) 100\% NPKS Zn (120: 38: 38: 20: $5 \mathrm{~kg} \mathrm{~N}, \mathrm{P}_{2} \mathrm{O}_{5}, \mathrm{~K}_{2} \mathrm{O}$, $\mathrm{S}$ and $\mathrm{Zn}-$ kharif and 150: 50: 50: $20: 5 \mathrm{~kg} \mathrm{~N}, \mathrm{P}_{2} \mathrm{O}_{5}$, $\mathrm{K}_{2} \mathrm{O}, \mathrm{S}$ and $\mathrm{Zn}-$ rabi), $\left.\mathrm{T}_{4}\right) \mathrm{T}_{3}$ minus $\mathrm{N}, \mathrm{T}_{5}$ ) $\mathrm{T}_{3}$ minus $\mathrm{P}, \mathrm{T}_{6}$ ) $\mathrm{T}_{3}$ minus $\mathrm{K}, \mathrm{T}_{7}$ ) $\mathrm{T}_{3}$ minus $\mathrm{PK}, \mathrm{T}_{8}$ ) $\mathrm{T}_{3}$ minus $\mathrm{S}, \mathrm{T}_{9}$ ) $\mathrm{T}_{3}$ minus $\left.\mathrm{Zn}, \mathrm{T}_{10}\right) \mathrm{T}_{3}$ minus $\left.\mathrm{S} \mathrm{Zn}, \mathrm{T}_{11}\right) 75 \% \mathrm{NPK}+\mathrm{S}+\mathrm{Zn}+\mathrm{PM} @ 4 \mathrm{t} \mathrm{ha}^{-1}$ and $\left.\mathrm{T}_{12}\right) 50 \% \mathrm{NPK}+\mathrm{S}+\mathrm{Zn}+\mathrm{PM}$ @ $4 \mathrm{t} \mathrm{ha}^{-1}$. The test crop was rice with variety ADT 43 (Kharif) and BPT 5204 (Rabi). The experiment was conducted in RBD design with three replications. The following biometric observations were recorded at tillering stage, panicle initiation and harvest stage viz., plant height, tiller production, chlorophyll content and yield characters viz., number of panicles per square, number of grains per panicle, panicle length, 1000 grain weight and grain and straw yield.

\section{RESULTS}

\section{Growth Attributes}

A cursory glance at the table 1 showed significant influence of balanced application of plant nutrients on plant height, tiller production and chlorophyll content of lowland rice over control in both the seasons. The tallest rice plant (41.5, 66.7,91.2cm- kharif, 51.2, 71.5, $94.5 \mathrm{~cm}$ - rabi), maximum tiller count $(18.7,21.9,20.5$ kharif, 21.5, 27, 24- rabi) and LAI (3.65, 4.21- kharif, 3.95, 4.41-rabi) was noticed in tillering, panicle initiation and harvest stages, respectively with $\mathrm{T}_{11}\left(75 \% \mathrm{NPK}+\mathrm{S}+\mathrm{Zn}+\mathrm{PM} @ 4 \mathrm{tha}^{-1}\right)$ and was comparable with $\mathrm{T}_{3}$ $(100 \% \mathrm{NPK}+\mathrm{S}+\mathrm{Zn})$ but superior to rest of the treatments. The growth progressively reduced from the maximum, when there was omission of one or more nutrients. Among the omission of nutrients, $\mathrm{T}_{4}$ (no nitrogen) recorded the lowest growth followed by $\mathrm{T}_{10}(\mathrm{~S}+\mathrm{Zn}), \mathrm{T}_{7}(\mathrm{NPK})$ and $\mathrm{T}_{8}(\mathrm{~N}, \mathrm{~S})$. Farmer's practice $\left(\mathrm{T}_{2}\right)$ also showed lower growth compared to balanced fertilization with INM strategy $\left(\mathrm{T}_{11}\right)$ and without $\left(\mathrm{T}_{3}\right)$.

\section{Yield Characters}

The statistical scrutiny of morphological data on yield characters shown in table 2 divulged that the yield attributes was significantly influenced by addition of various nutrients in balanced proportion either alone or in combination with organics over control and omission of one or more plant nutrients in both seasons. Among the 


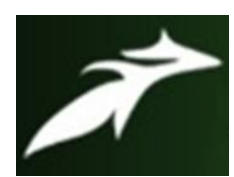

VINOTHKUMAR, R. et al, International Journal of Advances in Agricultural Science and Technology, Vol.8 Issue.2, February-2021, pg. 39-48

ISSN: 2348-1358

Impact Factor: 6.057

NAAS Rating: 3.77

treatments tested, application of balanced plant nutrients involving INM strategy made a striking difference and $\mathrm{T}_{11}\left(75 \% \mathrm{NPK}+\mathrm{S}+\mathrm{Zn}+\mathrm{PM} @ 4 \mathrm{t} \mathrm{ha}^{-1}\right)$ recorded the maximum number of panicles $\mathrm{m}^{-2}(293.4,297.9)$, number of grains panicle $\mathrm{e}^{-1}(179.6,203.5)$, number of filled grains panicle ${ }^{-1}(171.6,168.7)$, panicle length $(20.8,22.2 \mathrm{~m})$ and thousand grain weight (15.7.16.1g) and was comparable with $\mathrm{T}_{3}(100 \% \mathrm{NPK}+\mathrm{S}+\mathrm{Zn})$ but superior to rest of the treatments. Lack of any nutrient in the fertilizer schedule caused a reduction in yield attributes. Among the omission plots, yield characters were lowest with no nitrogen treatment $\left(\mathrm{T}_{4}\right)$ and was closely followed by omission of sulfur and zinc together $\left(\mathrm{T}_{10}\right)$. However, the lowest number of filled grains panicle ${ }^{-1}$ was noticed in rice plants which did not receive any essential plant nutrients $\left(T_{1}\right)$. Farmer's practice $\left(T_{2}\right)$ netted lower count on yield characters compared to balanced fertilization $\left(\mathrm{T}_{11}, \mathrm{~T}_{3}, \mathrm{~T}_{12}\right)$.

\section{Rice yield}

The perusal of data furnished in table 3 showed significant influence of balanced application of nutrients either alone or with organics caused a significant increase in rice yield in both seasons over control and nutrient omission plots. The grain yield ranged from 2745 to $5650 \mathrm{~kg} \mathrm{ha}^{-1}$ (kharif) and 2815 to $6080 \mathrm{~kg} \mathrm{ha}^{-1}$ (rabi). The grain yield response ranged from 270 to $2905 \mathrm{~kg} \mathrm{ha}^{-1}$ (kharif) and 340 to $3265 \mathrm{~kg} \mathrm{ha}^{-1}$ (rabi). Similarly, the straw yield ranged from 3321 to $6910 \mathrm{~kg} \mathrm{ha}^{-1}$ (kharif) and 3464 to $7418 \mathrm{~kg} \mathrm{ha}^{-1}$ (rabi). The highest grain $(5650,6080$ $\left.\mathrm{kg} \mathrm{ha}^{-1}\right)$ and straw yield $\left(6910,7418 \mathrm{~kg} \mathrm{ha}^{-1}\right)$ was noticed with balanced fertilization $\mathrm{T}_{11}(75 \% \mathrm{NPK}+\mathrm{S}+\mathrm{Zn}+$ PM @ $4 \mathrm{t} \mathrm{ha}^{-1}$ ) in kharif and rabi seasons, respectively. It was significantly superior to rest of the treatments. The best treatment which involves use of fertilization and organics recorded 5.7\% and 4.2\% increase over balanced fertilization of fertilizers alone during kharif and rabi seasons. Among the omission treatments, application of fertilizers devoid of nitrogen brought significant reduction in rice yield. Likewise, reduction in rice yield was noticed wherever nutrients were not applied.

\section{DISCUSSION}

Indian agriculture is now in era of multiple nutrient deficiencies. The decline in productivity of rice with continuous cropping was related to deficiency of $\mathrm{N}, \mathrm{P}, \mathrm{K}, \mathrm{S}$ and $\mathrm{Zn}$ and imbalanced nutrition (Kumar and Yadav, 2005). In the present study, all the growth parameters assessed were maximum with balanced fertilization involving INM over imbalanced fertilization. Stature of the plants leads to structure and capacities to capture sunlight to assimilate photosynthates by virtue of more leaves. As a plant grows taller, there are better possibilities to have more of effective leaves. Tillering is the outcome of the expansion of auxiliary buds which is closely associated with the nutritional condition of the mother culm. Tillering is an important trait for grain production and thereby it is critical aspect for the growth. Increased leaf area has implication for light interception and DMP to support plant growth and yield (Board, 2004). To achieve high yield, maximization of leaf area is an important factor of the crop (Singh and Agrawal, 2001). Variation in growth parameters among treatments was considered to be variation on the availability of major nutrients. Higher growth characters were attained in rice crop which had the benefit of balanced fertilization either through INM or chemical fertilizers. Growth promoting effect of $\mathrm{N}$ on plant can be explained on the basis of the fact that $\mathrm{N}$ supply increases the number and size of meristematic cells which leads to the formation of new shoot (Lawlor, 2002), higher tillering and LAI was due to favourable root growth and higher mobility of nitrogen in soil solution and its absorption by plant roots (Pramanik and Bera 2013). Phosphorus is a major component in ATP, the molecule that provides energy to the plant for metabolic processes such as photosynthesis, protein synthesis, nutrient translocation, nutrient uptake and respiration and it helped the plant grow faster in terms of plant height, tillering and LAI (Meena et al., 2014). K application was also found effective in producing a prolific root system by increasing root length and total root volume of rice which might have able to supply adequate potassium to plant in turn 


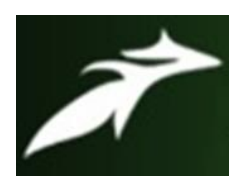

VINOTHKUMAR, R. et al, International Journal of Advances in Agricultural Science and Technology, Vol.8 Issue.2, February-2021, pg. 39-48

ISSN: 2348-1358

Impact Factor: 6.057

NAAS Rating: 3.77

improved various plant metabolism which reflected on higher plant height, tiller count and LAI (Shakouri et al., 2012).Sulfur is required early in the growth of rice plant and plays a crucial role in diversion of photosynthates towards at every growth stage and protein synthesis which might have improved the plant height, tiller count and LAI (Kalala et al., 2016). Systemic and positive response of plant height, tiller number and LAI to zinc addition might be mainly due to increment in internodes length, because of increment of protoplasm on cell wall material and consequently the increment in cell size that manifested in intermodal elongation (Zhang et al., 2013). Higher growth under INM practice might be due to gradual release of nutrients facilitated from organic and inorganic sources by offering more balanced nutrition to plants especially micronutrients, which has caused the plants to have maximum cell elongation or cell division and increased nutrient uptake to support growth has increased plant height, tiller number and LAI on addition of poultry manure and chemical fertilizer (Rakshit et al., 2008). The plant height, tiller count and LAI were hindered in rice plants which did not receive any one of five major nutrients in the fertilizer schedule and extent of reduction varied with nutrients and the maximum was noticed in $\mathrm{N}$ omission plots. Limitation of essential nutrients made the plant to underperform due to low metabolic processes in plants. Plants supplied with adequate amount of major nutrients (100\% RDF) and organics produced more height, number of tillers hill ${ }^{-1}$, dry matter production hill ${ }^{-1}$ and LAI at all the stages of crop growth was reported by (Singh et al., 2014).

Distinct positive effect of N, P, K, S \& Zn were noticed on yield attributes. All these parameters attained highest values with $(100 \% \mathrm{~N}, \mathrm{P}, \mathrm{K}, \mathrm{S} \& \mathrm{Zn})$ alone or with organics. Increase in yield components are associated with better nutrition, plant growth and increased nutrient uptake. In rice, sink lies in panicle and grains and the effect of major nutrients particularly $\mathrm{N}$ on yield attributes is primarily a function of assimilates accumulation and in turn facilitating higher $\mathrm{N}$ assimilation with adequate supply of photosynthates to grain (Pramanik and Bera, 2013). Effective translocation of assimilates to the sink might have resulted in sound filling of grains as revealed by the highest number of filled grains panicle ${ }^{-1}$ (Bouman et al., 2006). Phosphorus is a constituent of nucleic acid, phytin and phospholipids, it increased uptake resulted into better growth of plant and yield attributing characters. Phosphorus plays an important role in the translocation of assimilates to the panicles and also as a constituent of protoplasm. This explains the reason for the increased length of the panicle and number of grains per panicle. Hasamuzzaman et al. (2012) reported increase in yield attributes to P supply in rice soil. Potassium nutrition improves germination of pollen in the floret which leads to high spikelet fertility in rice. Cumulative effect of increased translocation of photosynthates to sink by potassium enhanced yield components (Rao et al., 2004). Zinc application improved nutritional environment of rhizosphere as well as plant system as evident from greater uptake of nutrients and ultimately metabolic and photosynthetic activity resulting in better development of yield attributes (Faisal Nadeem et al., 2015). Sulfur enhanced chlorophyll system, improved nutritional availability in the soil, which favourably influenced the carbohydrate metabolism due to the role of S in energy transformation and activation of carbon fixing enzymes. The higher yield attributes under combined application of organics and inorganics might be due to organic manures acting as slow-release source of $\mathrm{N}$ are expected to move closely to match with $\mathrm{N}$ and supply of other nutrients with demand of rice crop and this could reduce the $\mathrm{N}$ losses and also improved the NUE potential (Becker et al., 1994). Therefore, inorganic fertilizer in combination with organic manures caused the translocation of photosynthates from source to sink site that resulted in higher yield contributing factors of rice (Barik et al., 2009). Islam et al. (2010) reported beneficial effect of poultry manure on yield attributes. Application of low dose or no dose of $\mathrm{N}$ did not mitigate the nutrient need of the crop particularly during grain filling period resulting in poor yield characters. Huang et al. (2008) reported the similar result.

Balanced nutrition either through chemical fertilizers or INM caused significant increase in grain and straw yield over nutrient omission plots, farmers' practice and control in both seasons. The balanced fertilization 


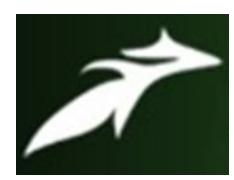

VINOTHKUMAR, R. et al, International Journal of Advances in Agricultural Science and Technology, Vol.8 Issue.2, February-2021, pg. 39-48

ISSN: 2348-1358

Impact Factor: 6.057

NAAS Rating: 3.77

involving INM recorded the highest yield compared to balanced fertilization (no organics) and 50\% reduction in $\mathrm{NPK}+\mathrm{S}+\mathrm{Zn}+\mathrm{PM} @ 4 \mathrm{tha}^{-1}$. Balanced fertilization not only accelerates nutrient uptake but also maintain soil nutrient balances leading to increased rice yield. Application of organic manures along with chemical fertilizers accelerated the microbial activity which increased NUE, enhance the availability of nutrients to the plants resulting higher nutrient uptake and finally reflected on rice yield. Poultry manure is an excellent organic fertilizer as it contains high NPK and other essential nutrients. Poultry manure is known to improve SOM and micronutrient status of the soil (Audu et al., 2015). Islam et al. (2014) reported maximum rice yield with $75 \%$ $\mathrm{N}, \mathrm{P}, \mathrm{K}, \mathrm{S} \& \mathrm{Zn}+\mathrm{PM}$ in Bangladesh soil. Grain yield due to balanced fertilization is associated with higher growth and yield characters. This was confirmed by significant linear relationship noticed between grain yields with growth and yield attributes (fig.1a and 1b). The omission of nutrient(s) from the fertilizer schedule caused a significant yield reduction compared to balanced fertilization. In grain yield, per cent reduction ranged from 47 to 13 (kharif) and 48.1 to 16.4 (rabi) and in straw yield, percent reduction ranged from 46 to 14 (kharif) and 46.8 to 15.1 (rabi). The highest reduction was noticed in nitrogen omission plots. Farmers' practice also showed a distinct reduction in yield on comparison with balanced fertilization (fig.2).

Nutrient imbalances in soil results in low fertilizer use efficiency, low yield. Akanda et al. (2012) noticed reduction in rice yield in the absence of $\mathrm{N}$ and $\mathrm{K}$ which could be due to lower chlorophyll content, nitrate reductases, total sugar and amino acids. Insufficient $\mathrm{S}$ supply can affect yield since $\mathrm{S}$ required for protein and enzyme synthesis (Zhao et al., 1999). Lack of zinc shows low level of auxin such as IAA and affects many metabolic processes in plant since zinc is cofactor for many enzymes. Dash et al. (2015) observed rice yield reduction in nutrient omission plots.

\section{Conclusions}

The study has clearly showed the importance of balanced fertilization involving INM strategy for sustainable rice productivity and omission of nutrients in the fertilizer schedule especially nitrogen has catastrophic effect on growth and yield of rice.

\section{References}

[1]. Acharya C.L and A. R. Sharma 2008. Integrated input management for improving nitrogen use efficiency and crop productivity. Indian Journal of Fertilizers, 4(2): 33-40, 43-50.

[2]. Akanda, K.E., K.M. Azad, U.D. Doula Pradhan, S. Rahman, M.S. Alam and S. Afrin. 2012. Effect of nitrogen and potassium on morpho-physiological characteristics of fine grain aromatic rice. Journal Agroforestry and Environment, 6 (1): 99-103

[3]. Audu, M., M. Haliru and M. Isah. 2015. Influence of poultry droppings on soil chemical properties and performance of rice (Oryza sativa L.) in Sokoto, Sudan Savanna Zone of Nigeria. International Journal Plant Soil Science, 7(2): 128-135.

[4]. Barah, B.C. and S. Pandey. 2005. Rainfed rice production systems in Eastern India: An on-farm diagnosis and policy alternatives. Indian Journal Agricultural Economics, 60(1): 110-136

[5]. Barik, A.K., A. Raj and R.K. Saha. 2009. Yield performance, economics and soil fertility through organic sources (vermicompost) of nitrogen as substitute to chemical fertilizers in wet season rice. Crop Research, (Hisar). 36: 4-7.

[6]. Becker, M., J.K. Ladha and J.C.G. Ottow. 1994. Nitrogen losses and lowland rice yield as affected by residue N release. Soil Science. Society American. Journal, 58(1): 1660-1665.

[7]. Board, 2004. Soybean cultivar differences on light interception and leaf area index during seed filling. Agronomy Journal, 96: 305-310.

[8]. Borah D., M. Ghosh, D. C. Ghosh and T. Gohain 2016. Integrated Nutrient Management in Rainfed Upland Rice in the North eastern Region of India. Agriculture Research. 5(3): 252-260. 


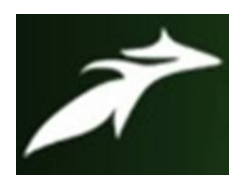

VINOTHKUMAR, R. et al, International Journal of Advances in Agricultural Science and Technology, Vol.8 Issue.2, February-2021, pg. 39-48

ISSN: 2348-1358

Impact Factor: 6.057

NAAS Rating: 3.77

[9]. Bouman, B.A.M., Yang, Xiaguang, Wang Huaqi, Zhimin, Zhao, Junfang and Chen, Bin. 2006. Performance of aerobic rice varieties under irrigated conditions in North China. Journal of Field Crops Research, 97: 53-65

[10]. Cassman, K G and Pingali P L. 1993. Extrapolating trends from long-term experiments to farmers fields: the case of irrigated rice systems in Asia. (In) Proceedings of the Working Conference on Measuring Sustainability Using Long-Term Experiments. Rothamsted Experimental Station, 28-30 April

[11].Dash, A.K., H.K. Singh, T. Mahakud, K.C. Pradhan and D. Jena. 2015. Interaction effect of nitrogen, phosphorus, potassium with sulphur, boron and zinc on yield and nutrient uptake by rice under rice-rice cropping system in Inceptisols of coastal Odisha. International Research Journal of Agriculture Science and Soil Science, 5(1): 14-21.

[12].Faisal Nadeem, Riaz Ahmad, Muhammad Ishaq Asif Rehmani, Ansar Ali, M.A.Alias Haji, A.Bukhsh, Javed Iqbal. 2015. Response of basmati rice (Oryza sativa L.) yield to time of application of phosphorus in combination with zinc under anaerobic. International Journal of Advance Research in Biological Science, 2(3): 35-42.

[13].Hasamuzzaman, M., M.H. Ali, M.F. Karim, S.M. Masum and J.A. Mahmud. 2012. Response of hybrid rice to different levels of nitrogen and phosphorus. International Research Journal of Applied and Basic Sciences., 3(12): 2522-2528

[14].Huang, J., F. He, X. Cui, R.J. Buresh, B. Xu, W. Gong and S. Peng. 2008. Determination optimal nitrogen rate for rice varieties using chlorophyll meter. Field Crops Research., 105: 70-80.

[15].Islam, M.S., A.K. Paul, A.S.M. Fazia Bari, Syfullah Shahriat, Sharmin Sultana and M.T. Hosain. 2014. Integrated effect of organic manures and nitrogen on yield contributing characters and yield of rice (BRRI dhan29). International Journal of Scientific and Research Publication, 4(11): 1-6

[16].Islam, M.S., M.Z. Islam, G.K.M. Rahman and M.A.A.H. Chowdhury. 2010. Effect of some secondary and micro nutrients along with organic amendments on T.aman. International Journal of Sustainable Crop Production5(4): 51-58.

[17].Kalala, A.M., N.A. Amuri and J.M.R. Semoka. 2016. Sulphur and zinc fertilization effects on growth and yield response of rice. International Journal of Plant \& Soil Science, 11(5): 1-12

[18].Lawlor, D.W. 2002. Carbon and nitrogen assimilation in relation to yield mechanisms are the key to understanding production systems. Journal of Experimental Botany., 53: 773-787

[19].Meena, R.K., Neupane, M.P. and Singh, S.P. 2014. Effect of phosphorus levels and bio-organic sources on growth and yield of rice (Oryza sativa L.). Indian Journal of Nutrition, 1(1): 105-110.

[20].Pramanik, P. and A.K. Bera. 2013. Effect of seedling age and nitrogen fertilizers on growth, chlorophyll content, yield and economics of hybrid rice (Oryza sativa L.). International Journal of Plant Production, 4(3): 3489-3499

[21].Rajendra Prasad. 2009. Efficient fertilizer use: The key to food security and better environment, Journal of Tropical Agriculture 47 (1-2) : 1-17

[22]. Rakshit, A.N., N.C. Sarkar and D. Sen. 2008. Influence of organic manures on productivity of two varieties of rice. Journal of Central European Agriculture, 9: 629-634.

[23].Rao, K.V., K. Surekha, D.K. Kundu and A.S.R. Prasad. 2004. Nutrient management to sustain productivity targets of irrigated rice. International symposium on rice, Hyderabad, pp. 416-417.

[24].Shakouri, M.J., A.V. Vajargah, M.G. Gavabar, S. Mafakheri, M. Zargar. 2012. Rice vegetative response to different biological and chemical fertilizer. Advances Environmental Biology Journal, 6: 859-863.

[25].Singh, D.K., P.C. Pandey and Shilpi Gupta. 2014. Long term addition of organics to sustain the system productivity of rice (Oryza sativa L.) - Wheat (Triticum aestivum L.) under Indo-Gangetic plains of India. International Journal of Scientific Research and Innovative Technology, 1(1):1-10

[26]. Singh, R. and S.K. Agarwal. 2001. Analysis of growth and productivity of wheat in relation to levels of FYM and nitrogen. Indian Journal Plant Physiology, 6: 279-283.

[27].Zhang Yue Qiang., L. Pang, P. Yun, D. Lin, W. Zhang, R. Yost, F. Zhang and C. Zou. 2013. Zinc fertilizer placement affects zinc content in maize plant. Plant and Soil, 372(1-2): 81-92

[28].Zhao, F.J., M.J. Hawkesferd and McGrath. 1999. Sulfur assimilation and effect on yield and quality of wheat. Journal of Cereal Science, 30: 11-17. 


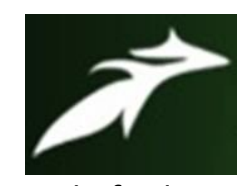

VINOTHKUMAR, R. et al, International Journal of Advances in Agricultural Science and Technology, Vol.8 Issue.2, February-2021, pg. 39-48

\section{ISSN: 2348-1358}

NAAS Rating: 3.77

Table 1. Effect of balanced fertilization on growth characters at different stages of rice crop growth

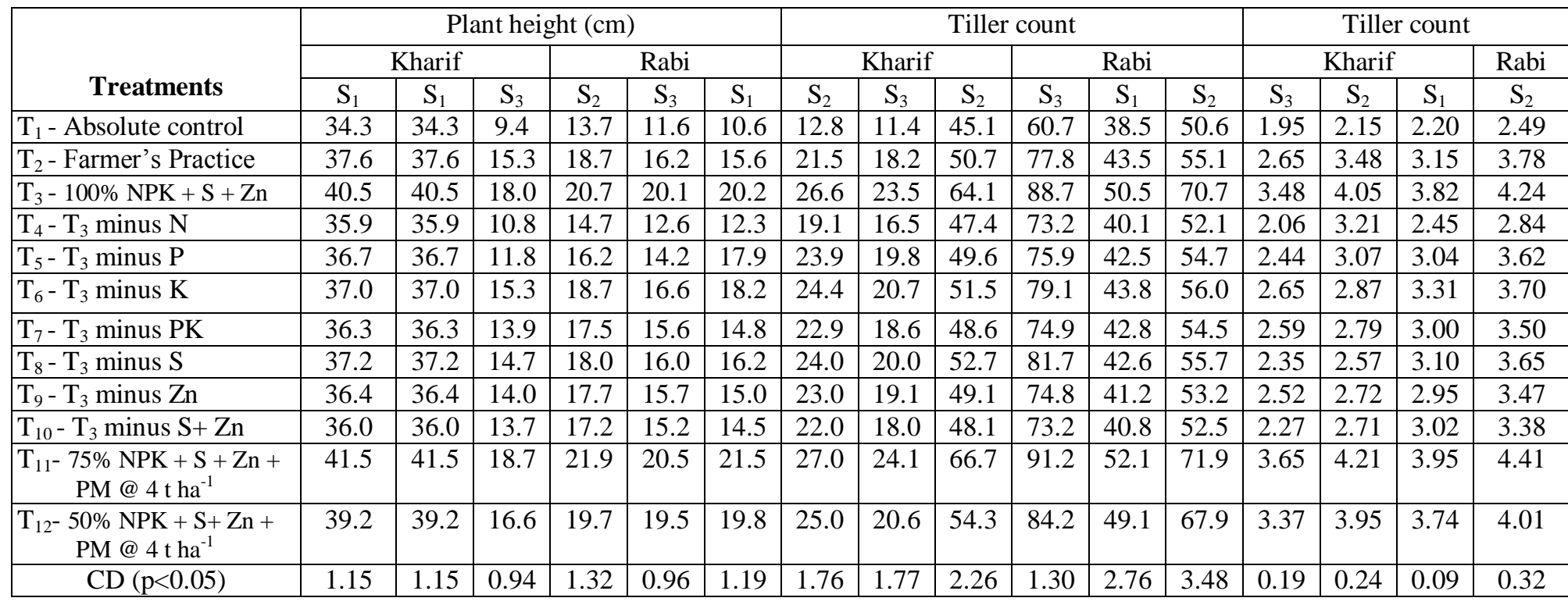

$\mathrm{S}_{1^{-}}$Tillering stage, $\mathrm{S}_{2^{-}}$Panicle initiation, $\mathrm{S}_{3^{-}}$Harvest stage 


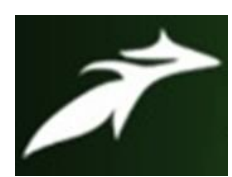

VINOTHKUMAR, R. et al, International Journal of Advances in Agricultural Science and Technology, Vol.8 Issue.2, February-2021, pg. 39-48

ISSN: 2348-1358

Impact Factor: 6.057

NAAS Rating: 3.77

Table 2. Effect of balanced fertilization on yield attributes of rice

\begin{tabular}{|c|c|c|c|c|c|c|c|c|c|c|}
\hline \multirow[b]{2}{*}{ Treatments } & \multicolumn{5}{|c|}{ Kharif } & \multicolumn{5}{|c|}{ Rabi } \\
\hline & $\begin{array}{c}\text { No. of } \\
\text { panicles } \\
\mathrm{m}^{-2}\end{array}$ & $\begin{array}{c}\text { No. of } \\
\text { grains } \\
\text { panicle }\end{array}$ & $\begin{array}{l}\text { No. of } \\
\text { filled } \\
\text { grains } \\
\text { panicle }^{1}\end{array}$ & $\begin{array}{l}\text { Panicle } \\
\text { length } \\
(\mathrm{cm})\end{array}$ & $\begin{array}{c}1000 \\
\text { grain } \\
\text { weight } \\
(\mathrm{g})\end{array}$ & $\begin{array}{c}\text { No. of } \\
\text { panicles } \\
\mathrm{m}^{-2}\end{array}$ & $\begin{array}{c}\text { No. of } \\
\text { grains } \\
\text { panicle }\end{array}$ & $\begin{array}{l}\text { No. of } \\
\text { filled } \\
\text { grains } \\
\text { panicle }^{1}\end{array}$ & $\begin{array}{l}\text { Panicle } \\
\text { length } \\
(\mathrm{cm})\end{array}$ & $\begin{array}{l}1000 \\
\text { grain } \\
\text { weight } \\
(\mathrm{g})\end{array}$ \\
\hline $\mathrm{T}_{1}$ - Absolute control & 236.5 & 122.5 & 103.4 & 19.0 & 14.3 & 225.4 & 127.8 & 100.9 & 17.5 & 14.0 \\
\hline $\mathrm{T}_{2}-$ Farmer's Practice & 268.9 & 158.3 & 146.5 & 19.8 & 15.0 & 271.7 & 280.9 & 145.2 & 19.9 & 15.1 \\
\hline $\mathrm{T}_{3}-100 \% \mathrm{NPK}+\mathrm{S}+\mathrm{Zn}$ & 287.4 & 173.9 & 164.7 & 20.4 & 15.3 & 291.6 & 300.5 & 165.6 & 21.8 & 15.8 \\
\hline $\mathrm{T}_{4}-\mathrm{T}_{3}$ minus $\mathrm{N}$ & 247.3 & 130.7 & 121.7 & 19.3 & 14.7 & 240.5 & 257.3 & 128.7 & 18.8 & 13.7 \\
\hline $\mathrm{T}_{5}-\mathrm{T}_{3}$ minus $\mathrm{P}$ & 270.3 & 160.4 & 149.0 & 19.9 & 15.0 & 273.4 & 277.8 & 148.3 & 19.4 & 15.4 \\
\hline $\mathrm{T}_{6}-\mathrm{T}_{3}$ minus $\mathrm{K}$ & 274.6 & 166.1 & 154.3 & 19.8 & 14.8 & 279.7 & 287.5 & 150.7 & 20.0 & 15.6 \\
\hline $\mathrm{T}_{7}-\mathrm{T}_{3}$ minus PK & 265.4 & 157.5 & 143.4 & 19.6 & 14.7 & 268.9 & 270.3 & 145.6 & 19.2 & 14.0 \\
\hline $\mathrm{T}_{8}-\mathrm{T}_{3}$ minus $\mathrm{S}$ & 275.1 & 168.7 & 156.9 & 19.5 & 15.1 & 271.8 & 285.3 & 151.3 & 19.7 & 15.2 \\
\hline $\mathrm{T}_{9}-\mathrm{T}_{3}$ minus $\mathrm{Zn}$ & 271.7 & 163.4 & 157.3 & 19.4 & 15.2 & 264.6 & 269.5 & 134.8 & 19.1 & 14.9 \\
\hline $\mathrm{T}_{10}-\mathrm{T}_{3}$ minus $\mathrm{S}+\mathrm{Zn}$ & 267.5 & 159.4 & 145.0 & 19.2 & 14.6 & 260.9 & 264.8 & 128.6 & 18.7 & 14.4 \\
\hline $\begin{array}{r}\mathrm{T}_{11^{-}}-75 \% \mathrm{NPK}+\mathrm{S}+ \\
\mathrm{Zn}+\mathrm{PM} @ 4 \mathrm{tha}^{1} \\
\end{array}$ & 293.4 & 179.6 & 171.6 & 20.8 & 15.7 & 297.9 & 303.5 & 168.7 & 22.2 & 16.1 \\
\hline $\begin{array}{l}\mathrm{T}_{12^{-}} 50 \% \mathrm{NPK}+\mathrm{S}+ \\
\mathrm{Zn}+\mathrm{PM} @ 4 \mathrm{t} \mathrm{ha}^{-1}\end{array}$ & 285.6 & 170.3 & 160.9 & 20.1 & 15.3 & 280.3 & 291.8 & 155.2 & 21.0 & 15.8 \\
\hline $\mathrm{CD}(\mathrm{p}<0.05)$ & 16.12 & 19.09 & 14.28 & 1.47 & 0.36 & 1.69 & 49.43 & 56.89 & 1.61 & 0.45 \\
\hline
\end{tabular}

Table 3. Effect of balanced fertilization on grain and straw yield of rice $\left(\mathrm{kg} \mathrm{ha}^{-1}\right)$

\begin{tabular}{|c|c|c|c|c|}
\hline \multirow[b]{2}{*}{ Treatments } & \multicolumn{2}{|c|}{ Kharif } & \multicolumn{2}{|c|}{ Rabi } \\
\hline & Grain & Straw & Grain & Straw \\
\hline $\mathrm{T}_{1}-$ Absolute control & 2745 & 3321 & 2815 & 3464 \\
\hline$T_{2}$ - Farmer's Practice & 4560 & 5535 & 4504 & 5721 \\
\hline $\mathrm{T}_{3}-100 \% \mathrm{NPK}+\mathrm{S}+\mathrm{Zn}$ & 5345 & 6510 & 5840 & 7242 \\
\hline $\mathrm{T}_{4}-\mathrm{T}_{3}$ minus $\mathrm{N}$ & 3015 & 3670 & 3155 & 3945 \\
\hline$T_{5}-T_{3}$ minus $P$ & 4450 & 5400 & 4645 & 5740 \\
\hline$T_{6}-T_{3}$ minus $K$ & 4895 & 5950 & 5078 & 6305 \\
\hline$T_{7}-T_{3}$ minus $P K$ & 4310 & 5250 & 4504 & 5560 \\
\hline$T_{8}-T_{3}$ minus $S$ & 4890 & 5970 & 5035 & 6253 \\
\hline $\mathrm{T}_{9}-\mathrm{T}_{3}$ minus $\mathrm{Zn}$ & 4837 & 5905 & 4983 & 6114 \\
\hline $\mathrm{T}_{10}-\mathrm{T}_{3}$ minus $\mathrm{S}+\mathrm{Zn}$ & 4540 & 5515 & 4705 & 5848 \\
\hline $\begin{array}{c}\mathrm{T}_{11}-75 \% \mathrm{NPK}+\mathrm{S}+\mathrm{Zn}+ \\
\text { PM @ } 4 \mathrm{t} \mathrm{h}^{-1}\end{array}$ & 5650 & 6910 & 6080 & 7418 \\
\hline $\begin{array}{c}\mathrm{T}_{12^{-}} 50 \% \mathrm{NPK}+\mathrm{S}+\mathrm{Zn}+ \\
\mathrm{PM} @ 4 \mathrm{t} \mathrm{ha}^{-1}\end{array}$ & 5100 & 6210 & 5175 & 6375 \\
\hline $\mathrm{CD}(\mathrm{p}<0.05)$ & 209 & 224 & 211 & 227 \\
\hline
\end{tabular}




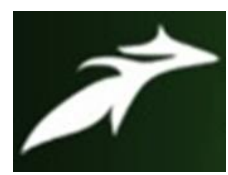

VINOTHKUMAR, R. et al, International Journal of Advances in Agricultural Science and Technology, Vol.8 Issue.2, February-2021, pg. 39-48

ISSN: 2348-1358

Impact Factor: 6.057

NAAS Rating: 3.77
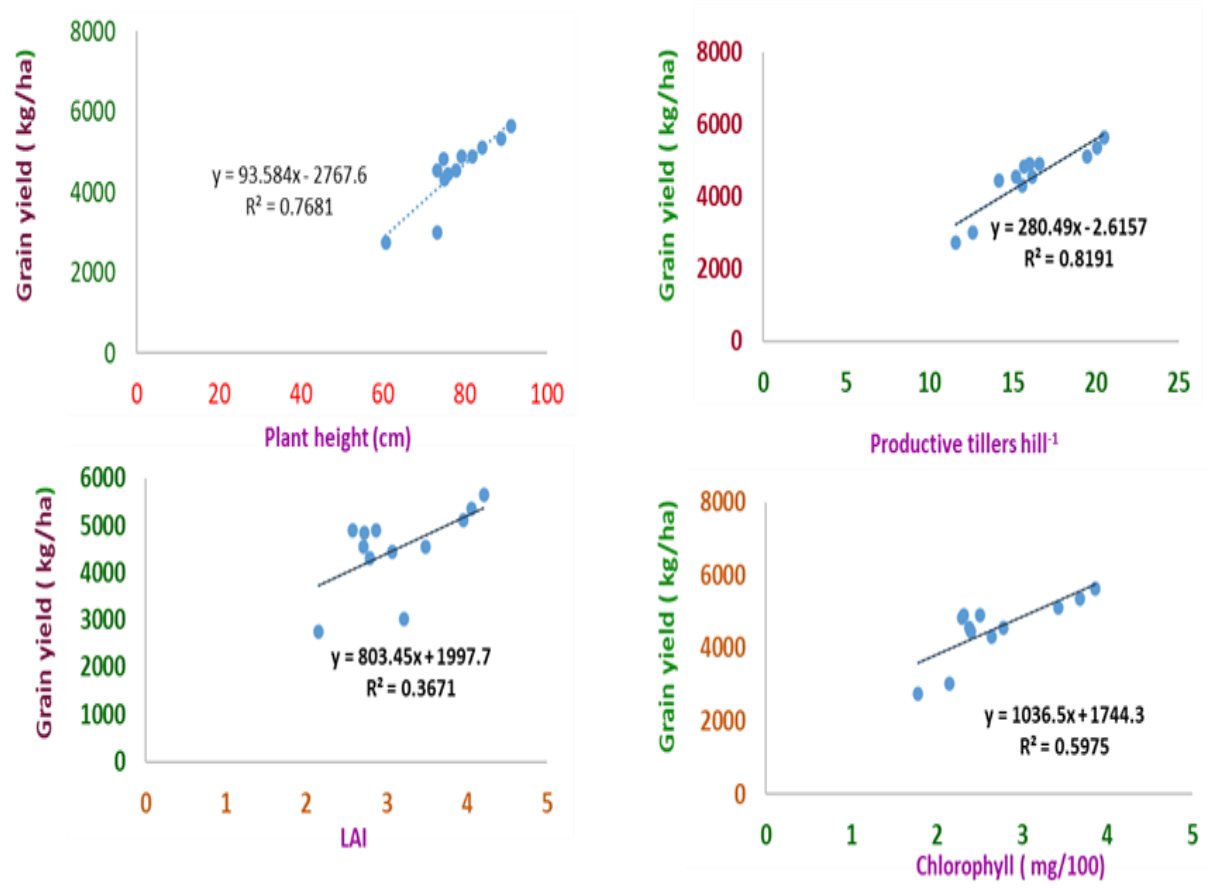

Fig.1a. Linear relationship between grain yield with growth characters
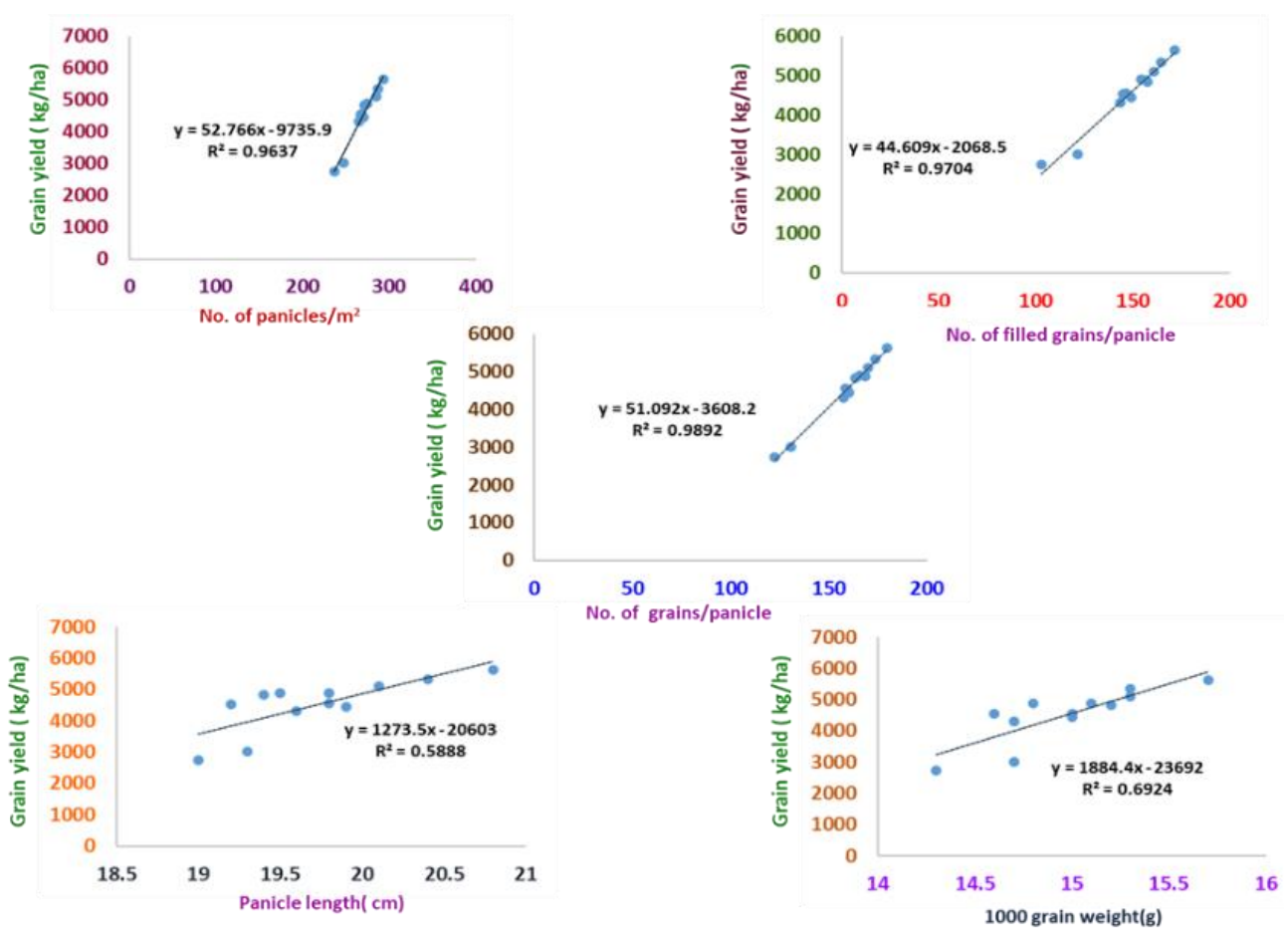

Fig.1b. Linear relationship between grain yield with yield attributes 


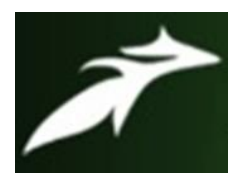

VINOTHKUMAR, R. et al, International Journal of Advances in Agricultural Science and Technology, Vol.8 Issue.2, February-2021, pg. 39-48

ISSN: 2348-1358

Impact Factor: 6.057

NAAS Rating: 3.77

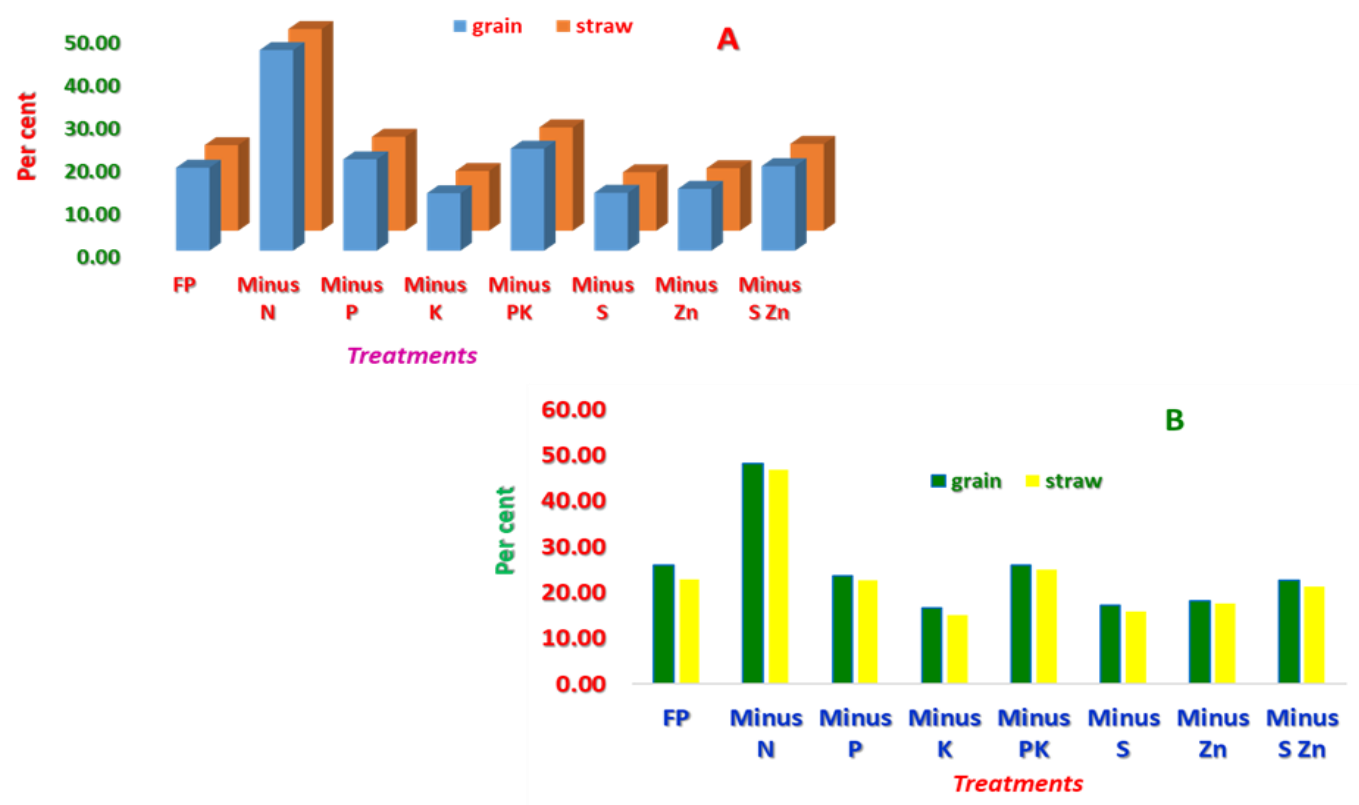

Fig.2. Effect of nutrient omission treatments on percent yield reduction over balanced fertilization a) kharif b) rabi 